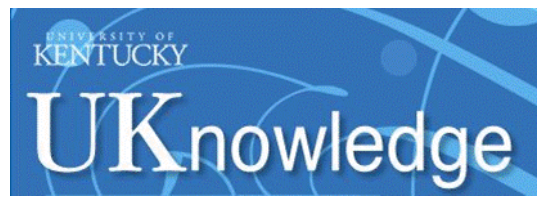

University of Kentucky

UKnowledge

Institute for the Study of Free Enterprise

Working Papers

Institute for the Study of Free Enterprise

$10-2020$

\title{
Has Anheuser-Busch Let the Steam Out of Craft Beer? The Economics of Acquiring Craft Brewers
}

\author{
Kenneth G. Elzinga \\ University of Virginia \\ Alexander J. McGlothlin \\ University of Kentucky, alexander.mcglothlin@uky.edu
}

Follow this and additional works at: https://uknowledge.uky.edu/isfe_papers

Part of the Economics Commons

Right click to open a feedback form in a new tab to let us know how this document benefits you.

\section{Repository Citation}

Elzinga, Kenneth G. and McGlothlin, Alexander J., "Has Anheuser-Busch Let the Steam Out of Craft Beer? The Economics of Acquiring Craft Brewers" (2020). Institute for the Study of Free Enterprise Working Papers. 30.

https://uknowledge.uky.edu/isfe_papers/30

This Research Paper is brought to you for free and open access by the Institute for the Study of Free Enterprise at UKnowledge. It has been accepted for inclusion in Institute for the Study of Free Enterprise Working Papers by an authorized administrator of UKnowledge. For more information, please contact UKnowledge@lsv.uky.edu. 


\title{
Has Anheuser-Busch Let the Steam Out of Craft Beer? The Economics of Aquiring Craft Bewers
}

\author{
Kenneth G. Elzinga \\ Alexander J. McGlothlin
}

October 2020

Institute for the Study of Free Enterprise

Working Paper 31

\author{
University of Kentucky \\ 244 Gatton College of Business and Economics \\ Lexington, KY 40506-0034 \\ http://isfe.uky.edu/
}

\section{Gatton College of




\title{
Has Anheuser-Busch Let the Steam Out of Craft Beer? The Economics of Acquiring Craft Brewers
}

\author{
Kenneth G. Elzinga · Alexander J. McGlothlin
}

Researchers own analyses calculated and based (or derived) in part on data from The Nielsen Company (US), LLC and from data in the Nielsen Datasets at the Kilts Center for Marketing Data Center at The University of Chicago Booth School of Business. The conclusions drawn from the Nielsen data are those of the authors and do not reflect the views of Nielsen. Nielsen is not responsible for and was not involved in analyzing and preparing the results found in this paper.

the date of receipt and acceptance should be inserted later

Acknowledgements The authors thank Luke W. Haynes for research assistance and Frank Scott, Federico Ciliberto, Orley Ashenfelter, and attendees of the International Industrial Organization Conference in Boston and the American Association of Wine Economists Conference in Vienna for comments and helpful suggestions.

Abstract The craft beer segment in the U.S. has grown from a meager 20 brewers in the 1980 s to over 7,000 today and is approaching a $15 \%$ market share. Macrobrewers initially responded by internal product differentiation but then began acquiring craft brewers, provoking concerns about the continuing viability of independent, local brewers. We analyze the economic consequences of the most prominent of these acquisitions: the Anheuser-Busch InBev (ABI) purchase of Goose Island in 2011. Using variation in pre-acquisition $\mathrm{ABI}$ market share to account for the effects of the distribution tier in the beer industry and the influence of macrobrewers on the distribution tier, we analyze price and quantity effects in the Midwest and mid-Atlantic states as well as the local region where Goose Island was founded. We also evaluate the effect on varieties of beer available to consumers in off-premise accounts to analyze the effect of ABI's acquisition on independent, local breweries who must jockey for shelf space with macrobrewers. By the usual metrics of merger retrospectives, we find large gains in sales for craft brewers as a result of ABI's entry by acquisition, possibly the result of marketing spillovers attracting new consumers to craft beer. We also find large negative effects on product variety, indicating greater difficulty for craft brewers to gain shelf placement in off-premise accounts. We find that these effects are most pronounced in Goose Island's regional birthplace of Illinois.

\section{Introduction}

In the United States, it has become common for large, established companies to acquire small, innovative firms. In recent years, Walmart, GM, Ford, Apple, Alphabet, Amazon, Facebook, Twitter, Microsoft and Yahoo together have acquired over 800 such firms. These acquisitions, being small, often are not publicized outside of trade and industry circles. However, the economic climate that this strategy of corporate control creates may significantly alter the entry and exit conditions for new entrants and can shape the product offerings of incumbent firms that make these acquisitions. As Wollmann (2019) points out, because of their size, many of these acquisitions fall outside the scope of the Hart-Scott-Rodino Act. For this reason, the antitrust authorities at the Department of Justice or the Federal Trade Commission might not take notice.

In the malt beverage industry, megabrewers such as Anheuser-Busch InBev (AB InBev or ABI) and SABMiller (MillerCoors) have acquired a number of craft brewers in the United States. Within beer industry circles, the acquisition of small, local brewers by large, national brewers is heartening to some and disheartening to others. ${ }^{1}$ On the one hand, the prospect of being acquired at a premium valuation can

Kenneth G. Elzinga

University of Virginia, Monroe Hall, Room 216, PO Box 400182, Charlottesville, VA 22904

Alexander J. McGlothlin

University of Kentucky, 550 South Limestone, Lexington, KY 40506

${ }^{1}$ According to Noel (2018), after the news of Goose Island's acquisition by ABI sunk in, friends of craft beer concluded: "Goose Island was a sellout. Anheuser-Busch was out to destroy craft beer. For twenty years, craft beer and Big Beer had been mostly parallel lines. The lines had intersected.” (p. 177) 
be attractive to a pioneering craft brewer and induce entry by aspiring entrepreneurs. On the other hand, consumers who value craft beer for its small business and local ownership appeal worry that acquisitions of craft brewers by large incumbent brewers will taint the cachet of the craft segment. ${ }^{2}$ Craft brewers who go it alone fear that their access to distribution channels will be foreclosed relative to that of the acquired craft brewers. Testing whether megabrewer-craft brewer combinations have anticompetitive consequences for independent craft brewers and their customers is the theme of this paper.

\section{The Craft Beer Segment: A Brief History}

The year 1965 marks the taproot of the craft beer industry in the United States, when Fritz Maytag assumed ownership of the Anchor Steam Beer Company in San Francisco and pioneered a way forward for small brewers in the U.S. beer industry (Elzinga et al., 2015). At the time, the beer industry was highly concentrated and output was largely homogeneous, consisting of lager beer.

While craft beer got its start with Maytag's entrepreneurial endeavors, the segment was slow to realize growth and popularity. Only 100 craft brewers existed in 1987. Since that time, there has been an explosion of new entrants. Over 7,000 craft breweries now operate in the United States. Most of these are small producers whose individual market share is de minimus (Elzinga et al., 2015). In fact, small-scale is part of the official definition put forth by the Brewers Association, which defines a craft brewer as small, ${ }^{3}$ independent, ${ }^{4}$ and, naturally, a brewer ${ }^{5}$. The growth in the craft segment has several explanations: a decrease in taxation of craft beer in $1978,{ }^{6}$ the expansion of brewpubs after their federal legalization in $1978,{ }^{7}$ growth in personal income, and consumer demand for product variety. ${ }^{8,9}$

The success of the craft beer movement was achieved in part through the product's differentiation compared to the relative homogeneity of the lager beer produced by the major brewers. Over time, the macrobeer industry evolved into primarily producing a "light beer" (i.e., low calorie) malt beverage whose popularity allowed the exploitation of scale economies. Today three of the four leading brands of beer sold in the U.S. are low-calorie beers..$^{10}$ Craft beer filled a demand gap that opened in part because of the close proximity in taste, quality, and price of the major brands. The craft industry also possesses public policy support, exemplified through the recent decrease of the federal excise tax on beer, a feature of the Craft Beverage Modernization and Tax Reform Act. ${ }^{11}$

Consumer demand for beer in the U.S. is supplied largely by ABI and MillerCoors. For some years, these firms could ignore the craft segment and did. However, in recent years, these firms have embarked on a wave of acquisitions of craft brewers. Craft brewers now produce over $12 \%$ of industry output (Brewers Association). The arrival of the craft segment is the most important contemporary development in the domestic beer industry. The interest and importance of craft beer is reflected in a growing literature. ${ }^{12}$

\footnotetext{
${ }^{2}$ If the cachet of the craft beer is based on locally owned, locally brewed product, the size and geographic footprint of Boston Beer sits outside both of these metrics. Boston Beer (primary brand, Samuel Adams) had sales in 2018 of 4.3 million barrels, making it the sixth largest brewer in the United States (Steinman, 2019a). Jim Koch, the founder of Boston Beer, is a member of the Bloomberg Billionaire group; his stature, and that of the firm he founded, also does not fit the conventional image of the scrappy craft brewer carving out a niche in an industry dominated by megabrewers.

3 "Annual production of 6 million barrels of beer or less (approximately 3 percent of U.S. annual sales). Beer production is attributed to a brewer according to rules of alternating proprietorships." (Brewer's Association, nd)

4 "Less than 25 percent of the craft brewery is owned or controlled (or equivalent economic interest) by a beverage alcohol industry member that is not itself a craft brewer." (Brewer's Association, nd)

5 "Has a TTB Brewer's Notice and makes beer." (Brewer's Association, nd)

${ }^{6}$ In 1978, Congress decreased the federal excise tax from $\$ 9.00 /$ barrel to $\$ 7.00 /$ barrel for the first 60,000 barrels produced by breweries with less than 2 million barrels in total annual sales.

7 While federal law permitted home brewing, legalization at the state level was not completed until 2013 when the last states, Alabama and Mississippi, legalized home brewing.

${ }^{8}$ See Tremblay and Tremblay (2011) and Silberberg (1985).

9 "American beer drinkers discovered variety. Tastes diversified. Anheuser-Busch could no longer simply suffocate competition. It needed craft beer. So it bought Goose Island.” (Noel, p. xi)

10 Bud Light, Coors Light, and Miller Lite.

${ }^{11}$ The Craft and Beverage Modernization and Tax Reform Act (CBMTRA) went into effect January 1, 2018 and will "sunset" on December 31, 2019. Under the bill, the federal excise tax decreased from $\$ 7.00 /$ barrel to $\$ 3.50 /$ barrel for the first 60 ,000 barrels of domestic brewers producing less than 2 million barrels annually (Brewer's Association, nd).

12 The best treatments are Acitelli (2013), The Audacity of Hops: The History of Americas Craft Beer Revolution and Lewis (2014), We Make Beer: Inside the Spirit and Artistry of Americas Craft Brewers. Booklength treatments of individual craft brewers include Beyond the Pale: The Story of Sierra Nevada Brewing Co. by Grossman (2013) and Beer for Pete's Sake by Slosberg (1998). Steve Hindy, one of the founders of The Brooklyn Brewery, also has written a history of craft brewers: The Craft Beer Revolution (Hindy, 2014).
} 


\section{Beer Distribution}

After Prohibition ended, a three-tier system was mandated in order to prevent the excesses and moral degradation that purportedly catalyzed the outlawing of alcoholic beverages under Prohibition. Federal law enabled states to mandate that there should be an independent distributor (i.e., the additional tier) positioned between the producer tier and the retailer tier. The supposed goal of requiring a third tier between the brewer and the retailer was to deter promotional strategies and actions on the part of a vertically integrated brewer-retailer that might stoke the demand for malt beverages in such a way as to cause alcoholism or alcohol-induced crime.

The result is that many distributors have contracts with major brewers to sell the brewer's products exclusively within a certain geographic region. This creates unique incentives for a brewer to structure contracts to induce the distributor to market its product line as opposed to its competitors' products to on-premise retailers (bars), as well as off-premise retailers (grocery stores, convenience stores, liquor stores, etc.).

Distributors also may control placement of products within the beer section of a supermarket or convenience store. As a "category captain," a distributor may determine what brands are placed next to each other, and the individual shelf level or cooler door where particular brands are displayed. Within the industry, shelf placement and shelf space are important marketing variables. For example, eye level products or products on an aisle endcap are more likely to be seen and bought by consumers. Pricing and shelf placement strategies may induce substitution towards one brand and away from another.

\section{Distribution by the Two Brewers}

As of 2016, ABI and MillerCoors sold about 2/3 of all beer in the U.S. ${ }^{13}$ Because of the existence of only two major sellers, there usually are only two major distributors in any one geographic area, one for the brand portfolio of ABI brands and one for the brand portfolio of MillerCoors. These same distributors also may contract with craft brewers in the area who want access to and distribution in their territory. Until recently, ABI and MillerCoors did not have a product to challenge craft beers in the market. However, with the acquisition of several craft breweries by the two dominant brewers, there is now concern among the craft segment that ABI and MillerCoors will use their influence with distributors to foreclose other craft brewers from on-premise as well as off-premise accounts. The National Beer Wholesalers Association spoke to this in a letter to the Department of Justice regarding the merger between ABI and SABMiller, noting,

"Through incentive programs to promote ABI beers at the expense of rival brands, influence over distribution management, substantial control through the equity agreement and by other means to control independent distributors, the DOJ has found that ABI can inhibit craft and rival brewers access to the market through ABIs distribution partners (National Beer Wholesalers Association, 2016)."

While the combined ABI and MillerCoors share of market (SOM) is large, it has been in a free-fall since the start of the twenty-first century. Over the past decade, ABIs volume fell almost 20 million barrels, almost all of this decrease taking place in ABIs two major brands, Budweiser and Bud Light. This loss in sales is the equivalent of shuttering four modern breweries. In terms of market share, ABI has lost approximately eight share points. (Steinman, 2019b). This loss in volume took place notwithstanding the acquisition of ten craft brewers and the acquisition itself of Anheuser-Busch by InBev. ${ }^{14}$

While the tailspin at MillerCoors has not matched that of ABI in reduced barrelage, in relative terms MillerCoors decline has been greater. In the past decade, MillerCoors volume dropped 14.5 million barrels, the equivalent of three modern breweries. The joint venture of Miller and Coors never experienced a year in which total sales for the combined firm grew. MillerCoors held a SOM of 30 percent in 2008; in 2018, the MillerCoors share was just under 24 (Steinman, 2019a). As macrobeer sales have decreased, their

\footnotetext{
${ }^{13}$ Unless cited otherwise, all figures are from the 2016 Beer Industry Update (Beer Marketer's Insights, 2016).

14 During this period, Anheuser-Busch has diversified through acquisition into other potables including tea, energy drinks, hard seltzer, and even spirits. Recently ABI acquired Cutwater Spirits, a firm founded by the same team that founded Ballast Point, a craft brewer acquired earlier by ABI. (Steinman, 2019a).
} 
distributors became wary about the future of Big Beer and focused their attention on growth sectors such as import brands, craft brands, and flavored malt beverages..$^{15}$ The macrobrewers have taken notice. ${ }^{16}$

Table 1 shows U.S. share of beer sales by segment, comparing 2018 to 2013. In 2013, Craft SOM was just under eight share points; Import SOM was just over thirteen. Imports now stand at just over seventeen; while Craft is just over twelve. Imported beer maintained a consistent segment share lead over craft beer, the delta between Import and Craft remaining stable at about five share points.

At one time in the U.S., imported beer primarily meant beer from Canada, Germany, and the Netherlands. No more. Table 2 shows the shipments of imported brands in 2018. Constellation's portfolio of Mexican brands now has five of the top ten brands being sold in the U.S. Almost all of the growth in imports is accounted for by sales growth from South of the border. Note the absence of any import beer among the top ten brands from North of the border. Once prominent Canadian brands in the Molson and LaBatt portfolio have faded.

\section{The Major Brewers and Craft Beer}

Prior to the expansion of craft brewers in the United States, the beer industry sustained a dramatic decrease in the number of producers. The number of conventional lager breweries in the U.S. fell from 421 in 1947 to 20 in 2006, as firms either merged or exited the market (Elzinga et al., 2015). This drop was the result of economies of scale in production and marketing, which benefitted the large macrobrewers but pushed most of the medium-sized brewers out of the market (Elzinga (2016), Tremblay and Tremblay (2011)).

High profile acquisitions and mergers at the top of the international macrobrewer food chain also have contributed to the diminishing number of conventional breweries. In 2002, South African Breweries acquired Miller Brewing Company to form SABMiller. In 2005, Molson Brewery of Canada and Coors Brewing Company merged to form the Molson Coors Brewing Company. In 2008, SABMiller and Molson Coors formed the joint venture, MillerCoors, for operations in the United States. Also, in 2008, Belgian brewing firm, InBev, acquired Anheuser-Busch to create Anheuser-Busch InBev (ABI). ${ }^{17}$ ABI engaged in a Brobdingnagian $\$ 107$ billion merger with SABMiller in 2016. As a result of that combination, Molson Coors assumed sole ownership of MillerCoors.

Production of "phantom" craft beer brands was the macrobrewers initial response to the growth of the craft brewing market. ${ }^{18}$ In 1988, Miller bought Jacob Leinenkugel Brewing Company, the first such acquisition. In 1995, Miller also purchased Celis Brewery and a 50\% share of Shipyard Brewing. In 2000, Miller shut down Celis Brewery and sold Shipyard back to the original owners. With the exception of Leinenkugel, which went on to become part of Miller's craft and import business development unit, Tenth and Blake Beer Company, these initial acquisitions were not distinguished by their commercial success. The real movement of Big Beer companies acquiring craft brewers came a decade later when ABI got involved.

\section{$6 \mathrm{ABI}$ and the Craft Segment}

In Barrel-Aged Stout and Selling Out: Goose Island, Anheuser-Busch, and How Craft Beer Became Big Business, Josh Noel noted “the announcement of Goose Island's \$38.8 million sale to the world's largest beer company, on March 28, 2011, functionally ended an era for craft beer-an era of collaboration and cooperation, growth, and good vibes, and the shared cause of building a lifeboat in a sea of Big Beer banality." (Noel, p. xi) Noel added,

\footnotetext{
${ }^{15}$ An example of a flavored malt beverage would be Mike's Hard Lemonade.

${ }^{16}$ Kostov (2018) and Bostwick (2018) of the Wall Street Journal both describe how the decrease in sales of macrobeer such as Bud Light as well as the rise in popularity of craft beer have prompted distributors to reconsider their business models.

${ }_{17}^{17}$ For detailed account of the hostile takeover of Anheuser-Busch, see Dethroning the King (Macintosh, 2011).

${ }^{18}$ Anheuser-Busch was the first mover in this product space with Elk Mountain Ale in 1994, followed by Red Wolf Lager brand that same year. Miller followed suit by introducing its Red Dog brand through Plank Road Brewery, an in-house subsidiary of Miller that focused on craft beer products. The most successful of these phantom brands was Blue Moon, developed by Coors in 1995. MillerCoors now sells over 2 million barrels of Blue Moon per year. Blue Moon's success prompted ABI's 2006 release of its similarly marketed brand Shock Top, which reached an annual production of 900,000 barrels in 2014.
} 
"Goose Island reached a unique place in the American craft beer industry. It was a rare hybrid, serving local, national, and international audiences. It made beer for Chicago, it made beer for stadiums and airport bars, and it was a brand to be exported to Europe and China, Australia and South America. After all the scaling and tweaks, Goose IPA was essentially Anheuser-Busch IPA. 312 was Anheuser-Busch Wheat Ale... All became tepid Big Beer reinventions of what they had been when made in Chicago." (Noel, p. 329)

Goose Island was a natural candidate for acquisition, ABI already had a minority stake in the company, and it was consistently the second or third largest craft brewer in the six-state area in and around Illinois each year from 2004-2009 leading up to the acquisition. In addition to purchasing stakes in Spiked Seltzer, Virtue Cider, and the Craft Brew Alliance, ${ }^{19}$ ABI has since purchased nine other craft breweries under its High End Brands subsidiary:

- Blue Point Brewing Co.(NewYork-based firm selling 60,00o barrels/year at time of purchase, acquired in 2014 for an estimated \$24 million)

- 10 Barrel Brewing Co. (Oregon-based firm selling 40,00o barrels/year at time of purchase, acquired in 2014 for an undisclosed amount)

- Elysian Brewing (Washington-based firm selling 54,00o barrels/year at time of purchase, acquired in 2015 for an undisclosed amount)

- Golden Road Brewing (California-based firm selling 45,00o barrels/year at time of purchase, acquired in 2015 for an undisclosed amount)

- Four Peaks Brewing Company (Arizona-based firm selling 70,00o barrels/year at time of purchase, acquired in 2015 for an undisclosed amount)

- Breckenridge Brewery (Colorado-based firm selling 70,00o barrels/year at time of purchase, acquired in 2015 for an undisclosed amount)

- Devils Backbone Brewing Company (Virginia-based firm selling 60,00o barrels/year at time of purchase, acquired in 2016 for an undisclosed amount)

- Karbach Brewing Company (Texas-based firm selling 40,00o barrels/year at time of purchase, acquired in 2016 for an undisclosed amount)

- Wicked Weed Brewing (North Carolina-based firm selling 40,00o barrels/year at time of purchase, acquired in 2017 for an undisclosed amount)

\section{MillerCoors and the Craft Segment}

Other macrobrewers have since made similar acquisitive forays into craft beer. MillerCoors acquired Terrapin Beer Company in 2011, Crispin Cider in 2012, Saint Archer Brewing in 2015, and Revolver Brewing and Hop Valley in 2016. Constellation, the American distributor of prominent Mexican beers Corona and Modelo, acquired Ballast Point in 2015 and Funky Buddha in 2017. Additionally, Heineken USA acquired a 50\% share of Lagunitas in 2015 before purchasing the remaining share of the company in 2017. This progression of acquisitions reveals the increased desire of Big Beer to cross the line between macrobrewed lagers and craft beer varieties to capitalize on the consumer demand for product differentiation and to integrate acquired craft brewers into their established distribution channels.

\section{A Case Study}

To better understand the economic consequences of craft beer acquisitions by a macrobrewer, we examine in detail the consequences of ABI's acquisition of Goose Island. Goose Island is a worthy "representative firm" (in Alfred Marshall's use of the term). Goose Island was the largest craft brewer in Chicago at the time of its acquisition; and it was acquired by the largest macrobrewer (ABI). ${ }^{20}$ The leading brand of Goose Island was " 312 " which is the area code for Chicago. What makes our use of the acquisition

\footnotetext{
19 The Craft Brew Alliance is a brewing company consisting of five beer and cider brands: Redhook, Widmer Brothers, Kona, Omission, and Square Mile Cider. CBA was founded in 2008 and then in 2013 sold a $32.2 \%$ share of the business to ABI, which became the company's distribution partner.

20 "[Goose Island] was an undeniably exciting place to work during an exciting time. The secret of variety, choice, and innovation was out; everyone wanted a piece of craft beer. Breweries were opening at the rate of one a day. Chicago had gone from one production brewery-Goose Island-to nearly a dozen. Goose Island was in the midst of a sixteen-year run of winning twenty-five medals at the Great American Beer Festival-at least once every year." (Noel, p. 146)
} 
especially fitting (if not ironic) is that Goose Island 312 is now brewed at an ABI brewery in Baldwinsville, New York (where the area code is 315$)^{21}$

\section{AB InBev Goose Island: The Competition Issue}

Economic theory provides several possible strategic responses that could be the consequence of a major brewer acquiring a craft brewer. Given the number of craft brewers, and the relative ease of entry into the craft segment, it is plausible that craft brewery acquisitions would have no price effect on craft beer. Thus, if the market for craft beer were competitive, ABI would have no ability to raise the price of Goose Island beer, and no incentive to lower its price. Under this scenario, there should be no antitrust concern. If the acquiring firm can exploit scale economies in production or take advantage of distribution economies in promoting the acquired brand to retail accounts, one would expect a decrease in the price of Goose Island beer and expansion of volume and sales. If this is the case, the antitrust authorities should applaud such acquisitions.

If ABI's acquisition of Goose Island affords ABI the ability to raise the price floor under craft beer by raising the price points of its mainline products (e.g., Budweiser and Busch), then such an acquisition may harm consumer welfare. Additionally, due to the regulatory characteristics of the three-tier system, ABI could use its influence on distributors to foreclose the market to rivals in the craft beer segment. This may differentially affect states based on the legal regimes that govern their specific markets for alcoholic beverages, as discussed in Burgdorf (2019). If either of these occur, such acquisitions merit the attention of the antitrust authorities.

\section{Data}

We use Nielsen scanner data provided by the Kilts Center for Marketing Data Center at the University of Chicago Booth School of Business to explore whether there is evidence of foreclosure. Specifically, we utilize the Retail Scanner Dataset to observe sales of beer at the month-store-product level. In the Nielsen dataset, sales are recorded at the end of each week, and a volume-weighted price is reported, though we aggregate up to the month level. ${ }^{22}$ We calculate both the total volume (in ounces) sold of each beer in each store in addition to the total dollar amount of each beer sold in each store. We use these to calculate the effective price per ounce of each brand of beer (e.g., Goose Island 312) at each store and total sales (total revenue) for each brand of beer at each store.

Due to sales promotions, stockpiling, and uneven consumption around occasions such as the Super Bowl and the Fourth of July, sales may be choppy at the week level. By aggregating sales to the month in which they were reported, we avoid the influence of outliers due to holiday or sporting event consumption spikes and the pitfalls of having too many zeroes in our data. We also reduce the number of data points, which allows us to expand the geographical scope of our sample and keep the computational burden of the large size of the Nielsen dataset manageable.

Product characteristics such as brand, package-type, and volume also are included. We restrict our sample to beer sold in six packs of 11.2 ounce or 12-ounce bottles. ${ }^{23}$ If different pack sizes were included, we would have to control for and explain the price differences due to quantity discounts. ${ }^{24}$ Additionally, packs including more than six bottles of beer are often only sold by macrobrewers and large craft brewers who have invested in the machinery to package larger pack sizes, creating a possible selection issue. Furthermore, it is unlikely consumers are substituting from six packs to other multi-packs as they do between six packs. By limiting our analysis to six packs, we move closer to an apples-to-apples instead of oranges-to-apples comparison.

\footnotetext{
${ }^{21}$ For a recent ("light" pun intended) account of ABI's acquisition of Goose Island, see Noel (2018).

${ }^{22}$ Beer sales are not evenly spaced across the week. Because of this, as well as for simplicity during data aggregation, we count the whole week's worth of sales in the month that sales are reported. For instance, if sales are reported on the third of the month, the entire week of sales are recorded as having occurred in that month.

23 Bottles that contain $\mathbf{1 1 . 2}$ ounces of beer hold one-third of a liter. European brewers and brewers that follow the European tradition may use this size instead of the 12-ounce size Americans use. To the untrained eye they are the same as those that hold 12 ounces of beer and are frequently placed next to each other in stores and sold as if they had the same fill.

${ }^{24}$ It is known that the major brewers engage in price discrimination as part of their competitive strategy but we can find no precedent in the literature studying this to follow and leave analysis of price discrimination in the beer industry to future research (Elzinga, 2016).
} 
For our results, we develop two samples based on brand information. The first contains all brands of craft beer sold in the Nielsen dataset. Descriptive statistics for this sample are located for the premerger time period in Table 3 and for the postmerger time period in Table 4. This sample was chosen to ascertain if the merger had an effect on craft brands in general, as has been feared by fans of the craft beer segment. As mentioned earlier, most craft brewers produce very little beer, and most sell primarily through a taproom or brewpub environment, or to on-premise accounts. Only the most successful brewers place their beer in the channels observed in the Nielsen dataset. This sample attempts to discern the effects of the acquisition on these craft brewers. The second sample contains beers produced by macrobrewers. ${ }^{25}$ This sample was chosen to see if the acquisition allowed the macrobrewers to raise prices on their brands through the alleviation of competitive pressure from the craft beer segment. Descriptive statistics for this sample are located for the premerger time period in Table 5 and for the postmerger time period in Table 6. From a market definition perspective, the brands in these two samples may be most likely to suffer adverse consequences from an acquisition of a craft brewer by a macrobrewer.

When the two megabrewers acquire craft brewers, the antitrust authorities might be concerned that independent craft brewers will be foreclosed from distribution. In our case study, the concern would be that ABI will use the acquisition of Goose Island to foreclose other craft brewers. This can be investigated by analyzing the first sample consisting of beers sold by craft brewers. If ABI has used Goose Island to foreclose or weaken other craft brewers in the market, we would expect quantity sold to decrease. If ABI has created a more efficient rival in Goose Island, we would expect prices to decrease, and quantities to either stay the same or increase, both procompetitive results.

A second concern is that the acquiring firm will absorb a craft brewer in order to alleviate the competitive pressure on the acquirer's own products. Here the concern would be that ABI will position Goose Island's pricing in a way that will induce substitution to the lager brands of the macrobrewers, leading to sustained or increased prices of these products and growth in their volume. This can be investigated by analyzing the second sample of beers produced by macrobrewers consisting of brands from ABI, MillerCoors, Heineken, Pabst, and Constellation. If ABI is able to position Goose Island to alleviate competitive pricing pressure on its mainstream brands, we should observe increased prices in these brands or we should see substitution from craft beer to mainstream brands, resulting in increased quantity sold.

Store characteristics also are included in this dataset; specifically, we identify the Designated Market Area (DMA), ${ }^{26}$ channel type, state, three-digit zip code, FIPS county code, and FIPS state code. ${ }^{27} \mathrm{We}$ also identify different retailers based on their store and corporate codes, though the true identity of each particular retailer is shielded in the dataset.

In addition to this information from Nielsen, we also add control variables for income, education, alcohol consumption from beer, wine, and spirits at the state-year level, and the year the state legalized brewpubs. We control for these because each of these measures is correlated with consumption of beer, and craft beer in particular.

Due to computational limitations, we apply several restrictions to our dataset. First, we limit our dataset geographically to Midwestern and mid-Atlantic states that are proximate to Goose Islands focal point of Chicago and would be the part of the country most likely to experience the effects, if any, of an aggressive expansion of Goose Island sales under the patronage of ABI. The territory we examine includes Washington, D.C., Delaware, Iowa, Illinois, Indiana, Kentucky, Maryland, Michigan, Minnesota, Missouri, New Jersey, Ohio, Pennsylvania, Virginia, Wisconsin, and West Virginia. We further limit our dataset only to beers sold between 2010 and 2013. This gives us both a pre- and post-period for the acquisition of Goose Island by ABI. ${ }^{28}$ The result is over four million observations at the brand-storemonth level in the craft beer sample and over six million observations in the macrobrewer sample. Using a difference-in-differences framework, we examine the effect of the merger on volume and pricing of craft beers and macro lagers.

\section{Estimation Approach}

Recall that the primary concern of competitors of Goose Island in the craft beer segment is that ABI will exploit distributor relationships to induce substitution towards Goose Island and away from "true craft"

\footnotetext{
25 We include all beers sold by ABI, Constellation, MillerCoors, Heineken, and Pabst.

26 These regions are determined by Nielsen based upon the regional reach of metro area commercial TV channels.

27 FIPS codes, or Federal Information Processing Standards, are five-digit codes that uniquely identify counties or county-equivalent jurisdictions in the United States.

28 The acquisition occurred on March 28, 2011.
} 
beers. If this is true, the potential effect of the merger should be stronger in stores and markets where $\mathrm{ABI}$ has a greater share of market and thus has more influence over their distributors. The National Beer Wholesalers Association (2016) expressed its concern that ABI

"encourages distributors to drop rival beers and replace it with an ABI owned "craft" to replace any lost sales. ABI may threaten the ability of a distributor to transfer its business. The pressure to drop rival beers does not end there. ABI executives have frequently visited distributors that choose to sell non-ABI products to encourage them otherwise, and publicly criticize distributors that carry non-ABI brands at trade meetings."

To address this, we would like to know the actual share of revenue or profits generated by ABI for each of its distributors in each of its retail stores. Unfortunately, that information is not publicly available. However, Nielsen data do allow us to find the market share at the store-month level captured by ABI products.

The variable ABI Market Share is defined as the premerger market share (determined by revenue) of $A B$ InBev branded products for a particular store. We implement our difference-in-differences model with this as our "treatment" or comparison variable, making this akin to an intent to treat specification. We adopt this because the economic concern of the merger is that $\mathrm{AB}$ InBev will use its market power to foreclose other craft brewers, or use its portfolio, now including Goose Island, to move pricing in such a way as to alleviate pressure on its mainline brands and portfolio in general. We expect that stores having significant sales of ABI brands in the premerger period should be more affected than stores whose revenue is largely sourced from other firms due to the influence of the distribution tier on off-premise sales. This specification also allows us to drill into the effects of the merger at the store level.

The Goose Island acquisition was announced on March 28, 2011, and we use this date to demarcate the premergerand postmerger time periods. ${ }^{29}$ Ourstandard errors are heteroscedasticity robust and clustered at the store level in all models..$^{30}$ We implement a fixed-effects model at the product-store level, which should control for time-invariant differences in individual stores' pricing strategies of individual brands.

Wemodel our difference-in-differences framework with five separate specifications and three outcome variables of interest. Our first specification regresses each dependent variable against a dummy variable that is equal to 1 for the post-acquisition time period (Post), the ABI Market Share variable, and an interaction term of these two variables (Post x ABI Market Share). Commensurate with the typical difference-in-differences approach, this interaction term is the variable of interest. If our estimates are causal, the coefficient on this term will reveal the positive or negative impact of the acquisition on each of the dependent variables of interest. We implement several improvements over the nave regression of our first specification.

Our second specification adds yearly time effects and our third specification adds year and DMA (Designated Market Area) interactions to the yearly time effects of our second specification. ${ }^{31}$ Our fourth specification adds year and retailer interactions to both the yearly effects and the year and DMA interactions. ${ }^{32}$ Our fifth, final, and preferred specification adds the control variables mentioned above to the fixed effects in the fourth specification.

The fifth specification is preferable for several reasons. First, it includes yearly time fixed effects to control for the significant growth of the craft beer industry over this period. Second, it includes year and Designated Market Area interaction terms. Craft beer demand and growth has a distinct geographical profile. They are concentrated in certain areas, and both are heterogeneous across areas and time. These interactions control for this. We include year and retailer interactions because, within the beer industry, there are distinct differences across channels in terms of breadth of offerings and types of beer sold. Typically, selection is wider at liquor stores than supermarkets, where selection is wider than convenience stores. That said, within these channels there also is variation in the selection of beers offered.

Retailers such as Walmart have a different inventory portfolio than Target, just as Whole Foods will offer different brands and package sizes than Kroger. ${ }^{33}$ However, due to the three-tier system, retailers may interact with distributors at a higher level than the individual store. This approach captures more heterogeneity than the typical channel-level analysis, but also takes into account the idiosyncrasies of the three-tier system. Moreover, by including the time interaction, we allow these effects to fluctuate as the craft beer landscape evolves and as retailers respond.

\footnotetext{
29 The postmerger time period begins in April of 2011 and the premerger time period ends in March of 2011.

${ }^{30}$ Note this is individual store level, not retailer level.

${ }^{31}$ We do not include month and DMA interactions due to computational restrictions.

$3^{2}$ We do not include month and retailer interactions due to computational restrictions.

33 In the Nielsen dataset, because retailers names are masked, our results do not imply anything concerning these specific stores.
} 
Finally, we include the battery of demographic controls (income, education, alcohol consumption, and year of brewpub legalization) to control for state level factors that may affect consumption patterns of craft beer. We choose to do this at the state level because we are unable to disaggregate available data to the DMA level. We apply these five specifications to our triple-difference framework as well.

This results in a difference-in-differences model that has the following specification:

$$
\begin{gathered}
\log \left(\text { price }_{i j k m t}\right)=\beta_{\mathrm{o}}+\beta_{1} \text { Post }_{t}+\beta_{2} \text { ABI Market } \text { Share }_{k}{ }^{+} \\
\beta_{3} \text { Post } * \text { ABI Market Share } k t+\beta_{4} \mathbf{X}_{\mathbf{i j k t}}{ }^{+} \\
\tau_{t}+\gamma_{m t}+\alpha_{k t}+\delta_{i j k m}+\varepsilon_{i j k m t}
\end{gathered}
$$

That is, we regress the log of price (or quantity) of a particular brand of beer (i) sold in a particular store $(\mathrm{j})$ that belongs to a particular retailer $(\mathrm{k})$ in a particular DMA $(\mathrm{m})$ at a particular time $(\mathrm{t})$ against the difference-in-differences variables and a battery of controls and fixed effects.

We study three outcome variables of interest: (1) the log of price per ounce; (2) log of total sales; and (3) the number of competing brands sold in the store. The first two outcome variables are conventional variables in merger retrospectives. Wewish to know if price has decreased, commensurate with efficiencies dominating merger related effects, or if price has increased, commensurate with coordination dominating merger related effects. Similarly, increasing total sales at the brand-store level may be indicative of a procompetitive merger and decreasing total sales may be indicative of an anticompetitive merger, such as would occur if $\mathrm{AB}$ InBev foreclosed other craft brewers from the market.

The craft beer segment competes for consumer patronage more through product differentiation than by price. Consumer welfare is a function not only of price but also quality. For this reason, we include a measure of the number of brands that compete within a store, to attempt to identify the effect of the acquisition on one quality metric, product variety. For each craft beer product, we calculate the number of distinct types of craft beers that are sold in the relevant store-month in the sample of craft beer and for each macro beer product we calculate the number of distinct types of macro beers that are sold in the relevant store-month for the sample of macro beers.

\section{Results: Craft Beer Sample}

We find no impact on the price of craft beer due to the acquisition of Goose Island by ABI. Results are in Table 9. This implies that while the acquisition did not have an anti-competitive effect on consumers from a rise in price of craft beer, there is also not evidence that the efficiency gains from ABI's superior technology and production capability were passed on to consumers of craft beer through aggressive price competition. We do find statistically significant evidence that the volume of sales of craft beer increased postmerger in stores that had larger market share premerger of ABI products. This implies that the amount of craft beer sold per week has increased in those stores that may have been more likely to be affected by the acquisition, perhaps as a result of aggressive marketing of Goose Island by ABI that may have spilled over to other brands. Results are located in Table 11. However, results on the impact of the acquisition on the number of craft beer brands sold, shown in Table 13, indicates that the number of craft beer brands has decreased in these stores, as we found statistically significant and negative effects on the number of competing craft beer brands sold in stores postmerger with a greater share of premerger ABI revenue. Together this is interesting, while there seems to be some confirmation of craft brewers' fear of being foreclosed on entering stores where ABI has a larger market share, conditional on gaining shelf space in these stores, the acquisition of Goose Island appears to be a boon to craft brewers.

\section{Results: Macro Beer Sample}

In terms of movement within macro beers, we find statistically significant evidence of postmerger increases in price of macro beer products in stores with larger premerger ABI market share, but statistically significant evidence of sales decreases for these products. Results are in Table 15 and Table 17. That these are opposite in direction show that while macrobrewers may have tried to jockey their products to a higher price point with the new portfolio of craft beer, sales levels were not maintained and it is unlikely this was profitable. This is mixed evidence towards macro brewers taking advantage of oligopoly power 
in these markets. In terms of number of competing macro beer brands, we find no statistical evidence of change postmerger, and show our results in Table 19.

\section{Results: Goose Island Sample}

Crucially, we would like to know the impact of the acquisition on sales of Goose Island beer itself. We investigate this by looking at a subsample of our craft beer sample consisting of only Goose Island brands. If the acquisition resulted in increased access and consumption of Goose Island it would be a boon to consumers, as would any price decreases passed through from efficiency gains made as a result of the acquisition. We first look at price effects and find that ABI maintained prices and did not pass through any achieved efficiencies to consumers, evidenced by no statistical change in price. Results are located in Table 21. Second, we look at sales. If ABI was aggressive in marketing Goose Island we would expect increases in sales of the brand. We cannot conclude the coefficient on the difference-in-differences interaction term is statistically significant but do observe positive coefficients on our regression of sales of some magnitude, providing weak evidence of an expansion of Goose Island sales after the ABI acquisition, as expected.

\section{Regional Analysis: Illinois}

It has become apparent that ABI's acquisitions have a distinct regional flavor to them. Each of the ten acquisitions is at the heart of a state or metro area that has seen tremendous growth in the craft segment. For that reason, a natural question is whether or not there are different effects in the regions these craft brewers are located compared to broader geographic areas. We first analyze the effect on craft beer sold in Illinois. Results are located in Table 25. We find much larger effects on sales and price than our more general analysis, for sales we find an effect almost five times that estimated in our more general sample as well as larger and statistically significant effects on price compared to that estimated in the more general sample. We find a negative effect on the number of brands of craft beer sold in individual stores more than twice that of our more general sample. It is clear that there have been much larger merger-related effects in the market for craft beer in Goose Island's home state of Illinois than elsewhere. This contrasts with our estimates from our macro beer sample in Illinois, which are located in Table 27. These coefficient estimates are similar for price and sales effects but larger, negative, and significant when analyzing the variety of brands of macro beer sold in stores compared to our more general geographic sample. Finally, we analyzed the impact on sales and price of Goose Island in Illinois, finding no impact on price but large, positive impacts on sales after the acquisition of Goose Island ten times that of the estimates from the more general sample. Results are located in Table 29. Together it appears that ABI has greatly expanded sales of Goose Island in Illinois at the expense of many smaller craft breweries.

\section{Channel Level Analysis}

We next analyze whether or not the acquisition had heterogeneous effects across different channel types. The Nielsen database allows us to observe whether each product was sold in a convenience store, drug store, food (grocery) store, or mass merchandiser. The exact identity of each of the retailers is hidden and unknown to us. We re-analyze the price, sales, and product variety effects in our macro, craft, and Goose Island samples by breaking the data into sub-samples for each of these four types of stores. Results are in Tables 31-45. We observe several interesting findings. First, we observe that increases in sales of craft beer are driven by stores in the convenience, drug, and mass merchandiser channels and not in grocery stores. We find large positive coefficients in these channels that range between roughly two and four times the magnitude observed in our full sample, and a smaller and statistically insignificant estimate on the interaction term in the grocery channel. This lends credence to the theory that ABI is spurring sales of craft beer in these channels where there is less variety of choice. Conditional on Goose Island being available on the shelf, ABI may drive more traffic to its own product option. Second, the loss of sales in macro beers are driven by drug stores but no meaningful loss is observed among mass merchandisers. This may be an artifact of our sample excluding non six-pack package sizes, as these two channels sell mainly very large or very small (single) packages of beer. Nonetheless, while estimates are generally in line with those of the full sample for convenience and grocery stores, drug stores observe an effect more than double the magnitude observed in the full sample. Finally, we observe weak price decrease in price of Goose Island beer in grocery stores as in the full sample, but large and positive increases in price in mass merchandise stores, suggesting that craft beer may be earning a premium in 
these channels.

\section{Conclusion}

One swallow does not make a Spring and one case study of an acquisition does not prove a proposition. Nonetheless, in watching for Spring we do look for swallows. For that reason, the ABI-Goose Island acquisition is a fitting case study of the economic consequences of combining a megabrewer with a prominent craft brewer. ${ }^{34}$ To the extent this case study is a harbinger of others, however, the standard price-quantity consequences studied in merger retrospectives of the ABI-Goose Island combination fail to confirm the fears that many had that the acquisition of Goose Island by ABI would hamper other craft brewers and consumers.

If the ABI-Goose Island amalgamation is a reflection of other such combinations, present and future, our study suggests that beer drinkers are not worse off in terms of the usual consumer welfare metrics of price and output. To the extent consumers value the Brandeisian merits of small business and derive utility from the purchasing the product of locally owned firms, the acquisition of craft brewers by megabrewers reduces the choice set of (true) craft beers with these attributes. Fortunately, through the rapid rise of on-premise outlets, the increasing supply of new entrants in the craft segment comes at a more rapid rate than the current propensity of megabrewers to acquire them or foreclose them from shelf space in off-premise accounts.

34 It is the one such acquisition to merit a book length treatment (Noel, 2018) whose author also extrapolates the lesson of this combination to the craft segment as a whole. 


\section{References}

Acitelli, T. (2013). The Audacity of Hops: The History of Americas Craft Beer Revolution. Chicago Review Press, Chicago.

Beer Marketer's Insights (2016). Beer Industry Update. New York.

Bostwick, W. (2018). Be a craft-beer connoisseur: How to find the brews for you. Wall Street Journal. Brewer's Association (n.d.). National beer sales \& production data.

Burgdorf, J. (2019). Impact of mandated exclusive territories in the us brewing industry: Evidence from scanner level data. International Journal of Industrial Organization, 63:376-416.

Elzinga, K. (2016). The beer industry. In Brock, J., editor, The Structure of American Industry (13th ed.). Prentice-Hall, Englewood Cliffs, NJ.

Elzinga, K., Tremblay, C., and Tremblay, V. (2015). Craft beer in the united states: History, numbers, and geography. Journal of Wine Economics, 10:242-274.

Grossman, K. (2013). Beyond the Pale: The Story of Sierra Nevada Brewing Co. John Wiley \& Sons, New Jersey.

Hindy, S. (2014). The Craft Beer Revolution: How a Band of Microbreweries is Transforming the World's Favorite Drink. St. Martin's Press, New York.

Kostov, N. (2018). Bud light bets on 'dilly dilly' to stem sliding sales. Wall Street Journal.

Lewis, S. (2014). We Make Beer: Inside the Spirit and Artistry of Americas Craft Brewers. St. Martin's Press, New York.

Macintosh, J. (2011). Dethroning the King: The Hostile Takeover of Anheuser-Busch, an American Icon. John Wiley \& Sons, New Jersey.

National Beer Wholesalers Association (2016). Re: Comments from the National Beer Wholesalers Association Concerning the Proposed Final Judgment in United States $v$. Anheuser-Busch InBev $S A / N V$ and SABMiller plc.

Noel, J. (2018). Barrel-Aged Stout and Selling Out: Goose Island, Anheuser-Busch, and How Craft Beer Became Big Business. Chicago: Chicago Review Press, Chicago.

Silberberg, E. (1985). Nutrition and the demand for taste. Journal of Political Economy, 93:881-900.

Slosberg, P. (1998). Beer for Pete's Sake: The Wicked Adventures of a Brewing Maverick. Brewers Publications, Boulder.

Steinman, B. (2019a). Beer marketer's insights, february 25, 2019. Unpublished paper.

Steinman, B. (2019b). Beer marketer's insights, march 11, 2019. Unpublished paper.

Tremblay, C. and Tremblay, V. (2011). Recent economic developments in the import and craft segments of the u.s. brewing industry. In Swinnen, J., editor, The Economics of Beer, pages 141-160. Oxford University Press, Oxford.

Wollmann, T. (2019). Stealth consolidation: Evidence from an amendment to the hart-scott-rodino act. American Economic Review: Insights, 1:77-94. 


\section{Tables}

Table 1: Beer Sales by Segment in the US

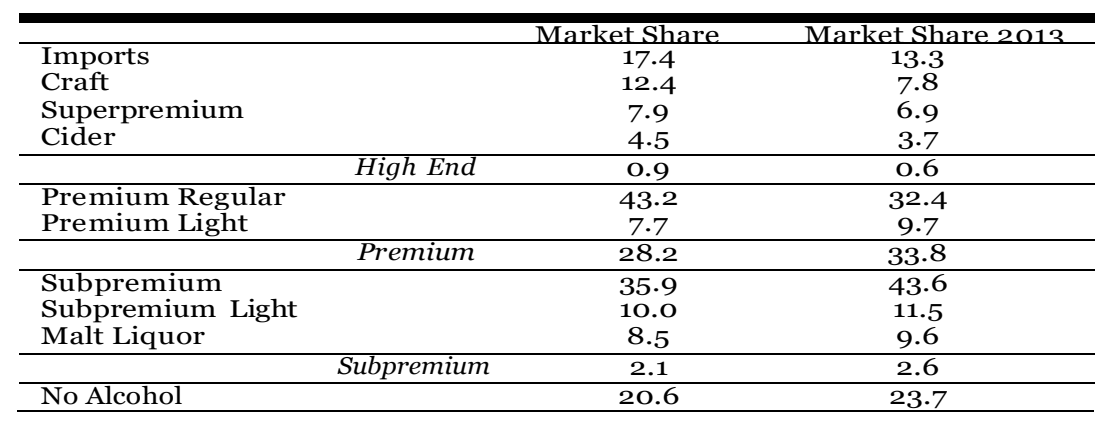

Table 2: *

Source: Beer Marketer's Insights

Table 3: Beer Sales by Segment in the US

\begin{tabular}{lccc}
\multicolumn{1}{c}{ Brand } & Bbls 2018 & Market Share & Bbls 2008 \\
\hline Corona Extra & 8,580 & 23.8 & 7,940 \\
Modelo & 8,180 & 22.7 & 1,810 \\
Heineken & 3,800 & 10.6 & 4,950 \\
Stella Artois & 2,675 & 7.4 & 755 \\
Dos Equis & 1,900 & 5.3 & 725 \\
Corona Light & 1,125 & 3.1 & 925 \\
Guinness & 1,110 & 3.1 & 980 \\
Corona & 730 & 2.0 & \\
Pacifico & 725 & 2.0 & 360 \\
Tecate & 680 & 1.9 & 1,515 \\
\hline Top 10 Brands & 29,505 & 82.0 & 19,960 \\
Others & 6,495 & 18.0 & 8,929 \\
\hline Total Imports & 36,000 & 100.0 & 28,889
\end{tabular}

Source: Beer Marketer's Insights

Table 4:*

Table 5: Premerger Summary Statistics, Craft Beer Sample

\begin{tabular}{lllcc} 
& mean & sd & min & $\max$ \\
\hline Six Pack Price & 8.192643 & 1.348875 & .01 & 24 \\
Six Pack Sold & 9.121971 & 17.46063 & 1 & 1698 \\
Total Sales & 72.78735 & 148.2007 & .01 & 15858.57 \\
Goose Island Sold in Store-week & .5444173 & .4980234 & O & 1 \\
ABI Market Share & .2284364 & .1168051 & O & .9860957 \\
brewpub legalization year & 1987.113 & 2.356039 & 1985 & 1993 \\
Percent bachelor's degree or higher, 25 and & 28.04414 & 4.72663 & 17.5 & 36.9 \\
Per Capita Income (chained 2012 dollars) & 48884.35 & 5264.827 & 36910 & 66706 \\
Per capita ethanol consumption from beer & 1.214892 & .1500962 & .89 & 1.49 \\
Per capita ethanol consumption from wine & .3279882 & .1025704 & .1 & .66 \\
Per capita ethanol consumption from & .7020477 & .1911048 & .44 & 1.36 \\
Total Brands Sold & 112.1514 & 57.30957 & 1 & 331 \\
Craft Beer Brands Sold & 44.37833 & 33.17063 & 1 & 189 \\
\hline Observations & 1111201 & & & \\
\hline
\end{tabular}

Number of Brands Sold in Store 
Table 6: Postmerger Summary Statistics, Craft Beer Sample

\begin{tabular}{lcccc}
\hline \hline & \multicolumn{1}{c}{ mean } & sd & min & max \\
\hline Six Pack Price & 8.672829 & 1.44457 & .01 & 65.94 \\
Six Pack Sold & 9.276056 & 20.14404 & .9333333 & 2663 \\
Total Sales & 78.15854 & 188.9804 & .01 & 31929.37 \\
Goose Island Sold in Store-week & .7156956 & .4510826 & 0 & 1 \\
ABI Market Share & .2289627 & .1312322 & 0 & 1 \\
Brewpub Legalization Year & 1987.084 & 2.271642 & 1985 & 1993 \\
Percent bachelor's degree or higher, 25 and & 29.02666 & 4.644906 & 18.5 & 37.4 \\
Per Capita Income (chained 2012 dollars) & 49900.8 & 4875.026 & 37405 & 68310 \\
Per capita ethanol consumption from beer & 1.176728 & .1455296 & .84 & 1.46 \\
Per capita ethanol consumption from wine & .3541886 & .0947028 & .1 & .72 \\
Per capita ethanol consumption from & .72547 & .1909979 & .46 & 1.63 \\
Total Brands Sold & 130.2513 & 67.95475 & 1 & 404 \\
Craft Beer Brands Sold & 64.28937 & 46.12406 & 1 & 267 \\
\hline Observations & 3479193 & & & \\
\hline
\end{tabular}

Table 7: Premerger Summary Statistics, Macro Beer Sample

\begin{tabular}{lcccc}
\hline \hline & mean & sd & min & max \\
\hline Six Pack Price & 6.433155 & 1.355273 & .01 & 20 \\
Six Pack Sold & 12.10633 & 15.37041 & .9333333 & 1671 \\
Total Sales & 75.21994 & 93.34719 & .01 & 8672.49 \\
Goose Island Sold in Store-week & .3956651 & .4889932 & o & 1 \\
ABI Market Share & .3054471 & .1716414 & O & 1 \\
Brewpub Legalization Year & 1987.449 & 2.627596 & 1985 & 1993 \\
Percent bachelor's degree or higher, 25 and & 27.85404 & 4.887537 & 17.5 & 36.9 \\
Per Capita Income (chained 2012 dollars) & 48445.99 & 5686.22 & 36910 & 68310 \\
Per capita ethanol consumption from beer & 1.192587 & .1455707 & .89 & 1.49 \\
Per capita ethanol consumption from wine & .3266767 & .1031089 & .1 & .69 \\
Per capita ethanol consumption from & .7004236 & .178198 & .44 & 1.52 \\
Total Brands Sold & 79.26268 & 51.63728 & 1 & 331 \\
Macro Beer Brands Sold & 38.58319 & 17.03259 & 1 & 86 \\
\hline Observations & 1953498 & & & \\
\hline
\end{tabular}

Table 8: Postmerger Summary Statistics, Macro Beer Sample

\begin{tabular}{lcccc}
\hline \hline & mean & sd & min & max \\
\hline Six Pack Price & 6.884017 & 1.339058 & .01 & 119.615 \\
Six Pack Sold & 12.17785 & 15.22255 & .9333333 & 1472 \\
Total Sales & 81.92596 & 103.0672 & .01 & 9936 \\
Goose Island Sold in Store-week & .5219289 & .499519 & o & 1 \\
ABI Market Share & .2982102 & .1720245 & 0 & 1 \\
Brewpub Legalization Year & 1987.412 & 2.579948 & 1985 & 1993 \\
Percent bachelor's degree or higher, 25 and & 28.82931 & 4.909575 & 18.5 & 37.4 \\
Per Capita Income (chained 2012 dollars) & 49369.57 & 5386.312 & 37405 & 68310 \\
Per capita ethanol consumption from beer & 1.159184 & .1469885 & .84 & 1.46 \\
Per capita ethanol consumption from wine & .3516101 & .1004513 & .1 & .72 \\
Per capita ethanol consumption from & .7353005 & .1877256 & .46 & 1.63 \\
Total Brands Sold & 89.16157 & 61.40486 & 1 & 404 \\
Macro Beer Brands Sold & 37.19947 & 16.65444 & 1 & 84 \\
\hline Observations & 4127748 & & & \\
\hline
\end{tabular}

Table 9: Fixed Effects Model (D-i-D), Craft Beer Sample (Dependent Variable = Log of Price)

\begin{tabular}{llcccc}
\hline & $(1)$ & $(2)$ & $(3)$ & $(4)$ & $(5)$ \\
\hline Post $\times$ ABI Market Share & $\begin{array}{l}\text { 0.0290 } \\
(0.00328)\end{array}$ & $\begin{array}{c}0.0303^{* * *} \\
(0.00330)\end{array}$ & $\begin{array}{c}\text { 0.00560 } \\
(0.00355)\end{array}$ & $\begin{array}{c}\text { 0.000951 } \\
(0.00316)\end{array}$ & $\begin{array}{c}\text { 0.000025 } \\
(0.00312)\end{array}$ \\
\hline Observations & 4589530 & 4589530 & 4589530 & 4589530 & 4589530 \\
\hline Time Fixed Effects? & & $\mathrm{Y}$ & $\mathrm{Y}$ & $\mathrm{Y}$ & $\mathrm{Y}$ \\
Time $\times$ DMA Interactions? & & & $\mathrm{Y}$ & $\mathrm{Y}$ & $\mathrm{Y}$ \\
Time $\times$ Retailer Interactions? & & & $\mathrm{Y}$ & $\mathrm{Y}$ \\
Demographic Controls & & & & $\mathrm{Y}$ \\
\hline \hline
\end{tabular}

Cluster robust standard errors in parentheses

${ }^{*} p<0.05,{ }^{* *} p<0.01,{ }^{* * *} p<0.001$

Table 10: *

Dependent variable is the log of price per ounce of a particular beer in a particular store. Sample includes all craft beer sold by brewers meeting the Brewers Association definition of a craft brewer in Washington, D.C., Delaware, Iowa, Illinois, Indiana, Kentucky, Maryland, Michigan, Minnesota, Missouri, New Jersey, Ohio, Pennsylvania, Virginia, Wisconsin, and West Virginia between 2010 and 2013 . Only $12 \mathrm{oz}$ or $11.2 \mathrm{oz}$ beer sold in packs of six are included in the sample. Time effects are dummy variables at the year level. Time $\mathrm{x}$ DMA interactions are interactions between year and Nielsen defined DMAs (Designated Market Area). Time x Retailer interactions are interactions between year and Nielsen retailer id (the identity of retailers is hidden in the data set). Demographic controls include income, education, and alcohol consumption from beer, wine, and spirits at the state-year level, and the year the state legalized brewpubs. 
Table 11: Fixed Effects Model (D-i-D), Craft Beer Sample (Dependent Variable = Log of Sales)

\begin{tabular}{lccccc}
\hline & $(1)$ & $(2)$ & $(3)$ & $(4)$ & $(5)$ \\
\hline Post $\times$ ABI Market Share & $\begin{array}{l}\text { 0.112 } \\
(0.0226)\end{array}$ & $\begin{array}{l}\text { 0.107 } \\
(0.0226)\end{array}$ & $\begin{array}{c}0.104^{* * *} \\
(0.0242)\end{array}$ & $\begin{array}{l}\text { 0.111 } \\
(0.0249)\end{array}$ & $\begin{array}{c}0.108^{* * *} \\
(0.0249)\end{array}$ \\
\hline Observations & 4590394 & 4590394 & 4590394 & 4590394 & 4590394 \\
\hline Time Fixed Effects? & & $\mathrm{Y}$ & $\mathrm{Y}$ & $\mathrm{Y}$ & $\mathrm{Y}$ \\
Time $\times$ DMA Interactions? & & & $\mathrm{Y}$ & $\mathrm{Y}$ \\
Time $\times$ Retailer Interactions & & & $\mathrm{Y}$ & $\mathrm{Y}$ \\
Demographic Controls & & & $\mathrm{Y}$ \\
\hline Cluster robust standard errors in parentheses
\end{tabular}

${ }^{*} p<0.05,{ }^{* *} p<0.01,{ }^{* * *} p<0.001$

Table 12: *

Dependent variable is the log of sales (in total dollars sold) of a particular beer in a particular store. Sample includes all craft beer sold by brewers meeting the Brewers Association definition of a craft brewer in Washington, D.C., Delaware, Iowa, Illinois, Indiana, Kentucky, Maryland, Michigan, Minnesota, Missouri, New Jersey, Ohio, Pennsylvania, Virginia, Wisconsin, and West Virginia between 2010 and 2013 . Only 12 oz or 11.2 oz beer sold in packs of six are included in the sample. Time effects are dummy variables at the year level. Time $\mathrm{x}$ DMA interactions are interactions between year and Nielsen defined DMAs (Designated Market Area). Time x Retailer interactions are interactions between year and Nielsen retailer id (the identity of retailers is hidden in the data set). Demographic controls include income, education, and alcohol consumption from beer, wine, and spirits at the stateyear level, and the year the state legalized brewpubs.

Table 13: Fixed Effects Model (D-i-D), Craft Beer Sample (Dependent Variable = Number of Brands Sold in Store)

\begin{tabular}{lccccc}
\hline & $(1)$ & $(2)$ & $(3)$ & $(4)$ & $(5)$ \\
\hline Post $\times$ ABI Market Share & $0.0186^{*}$ & $-45.54^{* * *}$ & $-40.59^{* * *}$ & $-29.88^{* * *}$ & $-29.63^{* * *}$ \\
& $(0.00935)$ & $(3.173)$ & $(2.846)$ & $(2.908)$ & $(2.886)$ \\
\hline Observations & 4590394 & 4590394 & 4590394 & 4590394 & 4590394 \\
\hline Time Fixed Effects? & & $\mathrm{Y}$ & $\mathrm{Y}$ & $\mathrm{Y}$ \\
Time $\times$ DMA Interactions? & & $\mathrm{Y}$ & $\mathrm{Y}$ & $\mathrm{Y}$ \\
Time $\times$ Retailer Interactions? & & & $\mathrm{Y}$ & $\mathrm{Y}$ \\
Demographic Controls & & & $\mathrm{Y}$ \\
\hline \hline
\end{tabular}

Cluster robust standard errors in parentheses

${ }^{*} p<0.05,{ }^{* *} p<0.01,{ }^{* * *} p<0.001$

Table 14: *

Dependent variable is the number of craft beer brands sold in a particular store. Sample includes all craft beer sold by brewers meeting the Brewers Association definition of a craft brewer in Washington, D.C., Delaware, Iowa, Illinois, Indiana, Kentucky, Maryland, Michigan, Minnesota, Missouri, New Jersey, Ohio, Pennsylvania, Virginia, Wisconsin, and West Virginia between 2010 and 2013 . Only 12 oz or 11.2 oz beer sold in packs of six are included in the sample. Time effects are dummy variables at the year level. Time $\mathrm{x}$ DMA interactions are interactions between year and Nielsen defined DMAs (Designated Market Area). Time $x$ Retailer interactions are interactions between year and Nielsen retailer id (the identity of retailers is hidden in the data set). Demographic controls include income, education, and alcohol consumption from beer, wine, and spirits at the stateyear level, and the year the state legalized brewpubs.

Table 15: Fixed Effects Model (D-i-D), Macro Beer Sample (Dependent Variable = Log of Price)

\begin{tabular}{lccccc}
\hline & $(1)$ & $(2)$ & $(3)$ & $(4)$ & $(5)$ \\
\hline Post $\times$ ABI Market Share & $\begin{array}{c}0.0639^{* * *} \\
(0.00259)\end{array}$ & $\begin{array}{l}0.062^{* * *} \\
(0.00259)\end{array}$ & $\begin{array}{c}0.0423^{* * *} \\
(0.00247)\end{array}$ & $\begin{array}{l}0.0294^{* * *} \\
(0.00236)\end{array}$ & $\begin{array}{c}0.0296^{* * *} \\
(0.00238)\end{array}$ \\
\hline Observations & 6080662 & 6080662 & 6080662 & 6080662 & 6080662 \\
\hline Time Fixed Effects? & & $\mathrm{Y}$ & $\mathrm{Y}$ & $\mathrm{Y}$ & $\mathrm{Y}$ \\
Time $\times$ DMA Interactions? & & & $\mathrm{Y}$ & $\mathrm{Y}$ \\
Time $\times$ Retailer Interactions? & & & $\mathrm{Y}$ & $\mathrm{Y}$ \\
Demographic Controls & & & $\mathrm{Y}$ \\
\hline \hline
\end{tabular}

Cluster robust standard errors in parentheses

${ }^{*} p<0.05,{ }^{* *} p<0.01,{ }^{* * *} p<0.001$

Table 16: *

Dependent variable is the log of price per ounce of a particular beer in a particular store. Sample includes macro beer sold by AB InBev, Constellation, MillerCoors, Heineken, and Pabst in Washington, D.C., Delaware, Iowa, Illinois, Indiana, Kentucky, Maryland, Michigan, Minnesota, Missouri, New Jersey, Ohio, Pennsylvania, Virginia, Wisconsin, and West Virginia between 2010 and 2013. Only 12 oz or 11.2 oz beer sold in packs of six are included in the sample. Time effects are dummy variables at the year level. Time $x$ DMA interactions are interactions between year and Nielsen defined DMAs (Designated Market Area). Time x Retailer interactions are interactions between year and Nielsen retailer id (the identity of retailers is hidden in the data set). Demographic controls include income, education, and alcohol consumption from beer, wine, and spirits at the stateyear level, and the year the state legalized brewpubs. 
Table 17: Fixed Effects Model (D-i-D), Macro Beer Sample (Dependent Variable = Log of Sales)

\begin{tabular}{lccccc}
\hline & $(1)$ & $(2)$ & $(3)$ & $(4)$ & $(5)$ \\
\hline Post $\times$ ABI Market Share & $\begin{array}{l}-0.00938 \\
(0.011)\end{array}$ & $\begin{array}{c}-0.0117 \\
(0.0110)\end{array}$ & $\begin{array}{c}-0.0571^{* * *} \\
(0.0119)\end{array}$ & $\begin{array}{r}-0.0799^{* * *} \\
(0.0119)\end{array}$ & $\begin{array}{r}-0.0808^{* * *} \\
(0.0119)\end{array}$ \\
\hline Observations & 6081246 & 6081246 & 6081246 & 6081246 & 6081246 \\
\hline Time Fixed Effects? & & $\mathrm{Y}$ & $\mathrm{Y}$ & $\mathrm{Y}$ & $\mathrm{Y}$ \\
Time $\times$ DMA Interactions? & & & $\mathrm{Y}$ & $\mathrm{Y}$ \\
Time $\times$ Retailer Interactions? & & & $\mathrm{Y}$ & $\mathrm{Y}$ \\
Demographic Controls & & & $\mathrm{Y}$ \\
\hline \hline Cluster robust standard errors in parentheses
\end{tabular}

${ }^{*} p<0.05,{ }^{* *} p<0.01,{ }^{* * *} p<0.001$

Table 18: *

Dependent variable is the log of sales (in total dollars sold) of a particular beer in a particular store. Sample includes macro beer sold by AB InBev, Constellation, MillerCoors, Heineken, and Pabst in Washington, D.C., Delaware, Iowa, Illinois, Indiana, Kentucky, Maryland, Michigan, Minnesota, Missouri, New Jersey, Ohio, Pennsylvania, Virginia, Wisconsin, and West Virginia between 2010 and 2013 . Only 12 oz or 11.2 oz beer sold in packs of six are included in the sample. Time effects are dummy variables at the year level. Time $\mathrm{x}$ DMA interactions are interactions between year and Nielsen defined DMAs (Designated Market Area). Time x Retailer interactions are interactions between year and Nielsen retailer id the identity of retailers is hidden in the data set). Demographic controls include income, education, and alcohol consumption from beer, wine, and spirits at the state-year level, and the year the state legalized brewpubs.

Table 19: Fixed Effects Model (D-i-D), Macro Beer Sample (Dependent Variable = Number of Brands Sold in Store)

\begin{tabular}{lccccc}
\multicolumn{2}{c}{ Sold in Store) } & & & \\
\hline Post $\times$ ABI Market Share & $(1)$ & $(2)$ & $(3)$ & $(4)$ & $(5)$ \\
& $-1.874^{* * *}$ & $-1.836^{* * *}$ & 0.287 & -0.344 & -0.303 \\
& $(0.278)$ & $(0.277)$ & $(0.303)$ & $(0.280)$ & $(0.282)$ \\
\hline Observations & 6081246 & 6081246 & 6081246 & 6081246 & 6081246 \\
\hline Time Fixed Effects? & & $\mathrm{Y}$ & $\mathrm{Y}$ & $\mathrm{Y}$ & $\mathrm{Y}$ \\
Time $\times$ DMA Interactions? & & & $\mathrm{Y}$ & $\mathrm{Y}$ \\
Time $\times$ Retailer Interactions? & & & $\mathrm{Y}$ & $\mathrm{Y}$ \\
Demographic Controls & & & & $\mathrm{Y}$ \\
\hline \hline
\end{tabular}

Cluster robust standard errors in parentheses

${ }^{*} p<0.05,{ }^{* *} p<0.01,{ }^{* * *} p<0.001$

Table 20:*

Dependent variable is the number of macro beer brands sold in a particular store. Sample includes macro beer sold by AB InBev, Constellation, MillerCoors, Heineken, and Pabst in Washington, D.C., Delaware, Iowa, Illinois, Indiana, Kentucky, Maryland, Michigan, Minnesota, Missouri, New Jersey, Ohio, Pennsylvania, Virginia, Wisconsin, and West Virginia between 2010 and 2013. Only $12 \mathrm{oz}$ or $11.2 \mathrm{oz}$ beer sold in packs of six are included in the sample. Time effects are dummy variables at the year level. Time $x$ DMA interactions are interactions between year and Nielsen defined DMAs (Designated Market Area). Time x Retailer interactions are interactions between year and Nielsen retailer id (the identity of retailers is hidden in the data set). Demographic controls include income, education, and alcohol consumption from beer, wine, and spirits at the state-year level, and the year the state legalized brewpubs.

Table 21: Fixed Effects Model (D-i-D), Goose Island Beer Sample (Dependent Variable = Log of Price)

\begin{tabular}{lccccc}
\hline & \multicolumn{1}{c}{$(\mathbf{1})$} & $(2)$ & $(3)$ & $(4)$ & $(5)$ \\
\hline Post $\times$ ABI Market Share & $-0.107^{* * *}$ & $-0.107^{* * *}$ & $-0.0345^{* * *}$ & -0.00720 & -0.0125 \\
$(0.00990)$ & $(0.00990)$ & $(0.00956)$ & $(0.00874)$ & $(0.00836)$ \\
\hline Observations & $\mathbf{1 8 7 8 7 7}$ & $\mathbf{1 8 7 8 7 7}$ & $\mathbf{1 8 7 8 7 7}$ & $\mathbf{1 8 7 8 7 7}$ & $\mathbf{1 8 7 8 7 7}$ \\
\hline Time Fixed Effects? & & $\mathrm{Y}$ & $\mathrm{Y}$ & $\mathrm{Y}$ & $\mathrm{Y}$ \\
Time $\times$ DMA Interactions? & & & $\mathrm{Y}$ & $\mathrm{Y}$ \\
Time $\times$ Retailer Interactions? & & & $\mathrm{Y}$ & $\mathrm{Y}$ \\
Demographic Controls & & &
\end{tabular}

${ }^{*} p<0.05,{ }^{* *} p<0.01,{ }^{* * *} p<0.001$

Table 22: *

Dependent variable is the log of price per ounce of a particular beer in a particular store. Sample includes beer produced by Goose Island in Washington, D.C., Delaware, Iowa, Illinois, Indiana, Kentucky, Maryland, Michigan, Minnesota, Missouri, New Jersey, Ohio, Pennsylvania, Virginia, Wisconsin, and West Virginia between 2010 and 2013. Only $12 \mathrm{oz}$ or 11.2 oz beer sold in packs of six are included in the sample. Time effects are dummy variables at the year level. Time x DMA interactions are interactions between year and Nielsen defined DMAs (Designated Market Area). Time x Retailer interactions are interactions between year and Nielsen retailer id (the identity of retailers is hidden in the data set). Demographic controls include income, education, and alcohol consumption from beer, wine, and spirits at the state-year level, and the year the state legalized brewpubs. 
Table 23: Fixed Effects Model (D-i-D), Goose Island Beer Sample (Dependent Variable = Log of Sales)

\begin{tabular}{|c|c|c|c|c|c|}
\hline & (1) & (2) & (3) & (4) & (5) \\
\hline Post $\times$ ABI Market Share & $\begin{array}{c}0.422^{* * *} \\
(0.0818)\end{array}$ & $\begin{array}{l}0.427^{* * *} \\
(0.0823)\end{array}$ & $\begin{array}{c}0.188^{*} \\
(0.0882)\end{array}$ & $\begin{array}{c}0.0609 \\
(0.0885)\end{array}$ & $\begin{array}{c}0.0607 \\
(0.0880)\end{array}$ \\
\hline Observations & 187877 & 187877 & 187877 & 187877 & 187877 \\
\hline Time Fixed Effects? & & $\mathrm{Y}$ & $\mathrm{Y}$ & $\mathrm{Y}$ & $\mathrm{Y}$ \\
\hline Time $\times$ DMA Interactions? & & & $\mathrm{Y}$ & $\mathrm{Y}$ & $\mathrm{Y}$ \\
\hline Time $\times$ Retailer Interactions? & & & & $\mathrm{Y}$ & $\mathrm{Y}$ \\
\hline Demographic Controls & & & & & $\mathrm{Y}$ \\
\hline
\end{tabular}

Cluster robust standard errors in parentheses

Table 24: *

Dependent variable is the log of sales (in total dollars sold) of a particular beer in a particular store. Sample includes beer produced by Goose Island in Washington, D.C., Delaware, Iowa, Illinois, Indiana, Kentucky, Maryland, Michigan, Minnesota, Missouri, New Jersey, Ohio, Pennsylvania, Virginia, Wisconsin, and West Virginia between 2010 and 2013. Only $12 \mathrm{oz}$ or $11.2 \mathrm{oz}$ beer sold in packs of six are included in the sample. Time effects are dummy variables at the year level. Time x DMA interactions are interactions between year and Nielsen defined DMAs (Designated Market Area). Time x Retailer interactions are interactions between year and Nielsen retailer id (the identity of retailers is hidden in the data set). Demographic controls include income, education, and alcohol consumption from beer, wine, and spirits at the state-year level, and the year the state legalized brewpubs.

Table 25: Fixed Effects Model, Craft Beer Sold in Illinois

\begin{tabular}{lccc}
\hline & $(1)$ & $(2)$ & $(3)$ \\
\hline Post $\times$ ABI Market Share & $\begin{array}{c}0.475^{* * *} \\
(\mathbf{0 . 1 3 4})\end{array}$ & $\begin{array}{c}\text { 0.0348** } \\
(\mathbf{0 . 0 1 2 1})\end{array}$ & $\begin{array}{c}-80.62^{* * *} \\
\text { (13.76) }\end{array}$ \\
\hline Observations & 586839 & 586787 & 586839 \\
\hline Dependent Variable? & Log of Sales & Log of Price & Number of Brands \\
Time Fixed Effects? & Y & Y & Y \\
Time $\times$ DMA Interactions? & Y & Y & Y \\
Time $\times$ Retailer Interactions? & Y & Y & Y \\
Demographic Controls & Y & Y & Y \\
\hline \hline
\end{tabular}

Standard errors in parentheses

${ }^{*} p<0.05,{ }^{* *} p<0.01,{ }^{* * *} p<0.001$

Table 26: *

Sample includes all craft beer sold by brewers meeting the Brewers Association definition of a craft brewer in Illinois between 2010 and 2013. Only $12 \mathrm{oz}$ or $11.2 \mathrm{oz}$ beer sold in packs of six are included in the sample. Time effects are dummy variables at the year level. Time $\mathrm{x}$ DMA interactions are interactions between year and Nielsen defined DMAs (Designated Market Area). Time $\mathrm{x}$ Retailer interactions are interactions between year and Nielsen retailer id (the identity of retailers is hidden in the data set). Demographic controls include income, education, and alcohol consumption from beer, wine, and spirits at the state-year level, and the year the state legalized brewpubs.

Table 27: Fixed Effects Model, Macro Beer Sold in Illinois

\begin{tabular}{lccc}
\hline & $(1)$ & $(2)$ & $(3)$ \\
\hline Post $\times$ ABI Market Share & 0.0630 & -0.00563 & $-5.757^{* * *}$ \\
& $(0.0651)$ & $(0.00611)$ & $(0.889)$ \\
\hline Observations & 706790 & 706633 & 706790 \\
\hline Dependent Variable? & Log of Sales & Log of Price & Number of Brands \\
Time Fixed Effects? & Y & Y & Y \\
Time $\times$ DMA Interactions? & Y & Y & Y \\
Time $\times$ Retailer Interactions? & Y & Y & Y \\
Demographic Controls & Y & Y & Y \\
\hline \hline Standard errors in parentheses & & &
\end{tabular}

Standard errors in parentheses

Table 28: *

Sample includes macro beer sold by AB InBev, Constellation, MillerCoors, Heineken, and Pabst in Illinois between 2010 and 2013. Only $12 \mathrm{oz}$ or $11.2 \mathrm{oz}$ beer sold in packs of six are included in the sample. Time effects are dummy variables at the year level. Time $\mathrm{x}$ DMA interactions are interactions between year and Nielsen defined DMAs (Designated Market Area). Time x Retailer interactions are interactions between year and Nielsen retailer id (the identity of retailers is hidden in the data set). Demographic controls include income, education, and alcohol consumption from beer, wine, and spirits at the state-year level, and the year the state legalized brewpubs. 
Table 29: Fixed Effects Model, Goose Island Beer Sold in Illinois

\begin{tabular}{lcc}
\hline & $(1)$ & $(2)$ \\
\hline Post $\times$ ABI Market Share & $\begin{array}{l}0.603^{*} \\
(0.303)\end{array}$ & $\begin{array}{c}-0.01000 \\
(0.0220)\end{array}$ \\
\hline Observations & 66616 & 66616 \\
\hline Dependent Variable? & Log of Sales & Log of Price \\
Time Fixed Effects? & Y & Y \\
Time $\times$ DMA Interactions? & Y & Y \\
Time $\times$ Retailer Interactions? & Y & Y \\
Demographic Controls & Y & Y \\
\hline \hline Standard errors in parentheses & & \\
${ }^{*} p<0.05,{ }^{* *} p<0.01,{ }^{* * *} p<0.001$ & &
\end{tabular}

Table 30: *

Sample includes beer produced by Goose Island in Illinois between 2010 and 2013 . Only 12 oz or 11.2 oz beer sold in packs of six are included in the sample. Time effects are dummy variables at the year level. Time $\mathrm{x}$ DMA interactions are interactions between year and Nielsen defined DMAs (Designated Market Area). Time x Retailer interactions are interactions between year and Nielsen retailer id the identity of retailers is hidden in the data set). Demographic controls include income, education, and alcohol consumption from beer, wine, and spirits at the state-year level, and the year the state legalized brewpubs.

Table 31: Fixed Effects Model, Craft Beer Channel Sub-analysis (Dependent variable $=$ Log of Price)

\begin{tabular}{lcccc}
\hline & $(1)$ & $(2)$ & $(3)$ & $(4)$ \\
\hline Post $\times$ ABI Market Share & $\begin{array}{c}\text { O.00987 } \\
(0.0112)\end{array}$ & $\begin{array}{c}\text { 0.0214 } \\
(0.0128)\end{array}$ & $\begin{array}{c}-0.00678^{*} \\
(0.00312\end{array}$ & $\begin{array}{c}-0.0124 \\
(0.0146)\end{array}$ \\
\hline Observations & 48085 & 301425 & 4067326 & 173558 \\
\hline Store Type & Convenience & Drug & Food & Mass \\
Time Fixed Effects? & $\mathrm{Y}$ & $\mathrm{Y}$ & $\mathrm{Y}$ & $\mathrm{Y}$ \\
Time $\times$ DMA Interactions? & $\mathrm{Y}$ & $\mathrm{Y}$ & $\mathrm{Y}$ & $\mathrm{Y}$ \\
Time $\times$ Retailer Interactions? & $\mathrm{Y}$ & $\mathrm{Y}$ & $\mathrm{Y}$ & $\mathrm{Y}$ \\
Demographic Controls & $\mathrm{Y}$ & $\mathrm{Y}$ & $\mathrm{Y}$ & $\mathrm{Y}$ \\
\hline \hline Standard errors in parentheses & & & & \\
${ }^{*} p<0.05{ }^{* *} p<0.01{ }^{* * *} p<0.001$ & & & &
\end{tabular}

Table 32: *

Dependent variable is the log of price per ounce of a particular beer in a particular store. Sample includes all craft beer sold by brewers meeting the Brewers Association definition of a craft brewer in Washington, D.C., Delaware, Iowa, Illinois, Indiana, Kentucky, Maryland, Michigan, Minnesota, Missouri, New Jersey, Ohio, Pennsylvania, Virginia, Wisconsin, and West Virginia between 2010 and 2013 . Only 12 oz or 11.2 oz beer sold in packs of six are included in the sample. Time effects are dummy variables at the year level. Time $\mathrm{x}$ DMA interactions are interactions between year and Nielsen defined DMAs (Designated Market Area). Time x Retailer interactions are interactions between year and Nielsen retailer id (the identity of retailers is hidden in the data set). Demographic controls include income, education, and alcohol consumption from beer, wine, and spirits at the state-year level, and the year the state legalized brewpubs.

Table 33: Fixed Effects Model, Craft Beer Channel Sub-analysis (Dependent variable = Log of Sales)

\begin{tabular}{lcccc}
\hline & $(1)$ & $(2)$ & $(3)$ & $(4)$ \\
\hline Post $\times$ ABI Market Share & $\begin{array}{l}0.391^{* *} \\
(0.142)\end{array}$ & $\begin{array}{c}0.187^{* * *} \\
(0.0474)\end{array}$ & $\begin{array}{c}\text { O.0602 } \\
(0.0330)\end{array}$ & $\begin{array}{c}0.255^{* *} \\
(0.0834)\end{array}$ \\
\hline Observations & 48085 & 301425 & 4067326 & 173558 \\
\hline Store Type & Convenience & Drug & Food & Mass \\
Time Fixed Effects? & Y & Y & Y & Y \\
Time $\times$ DMA Interactions? & Y & Y & Y & Y \\
Time $\times$ Retailer Interactions? & Y & Y & Y & Y \\
Demographic Controls & Y & Y & Y & Y \\
\hline
\end{tabular}

Standard errors in parentheses

${ }^{*} p<0.05,{ }^{* *} p<0.01,{ }^{* * *} p<0.001$

Table 34: *

Dependent variable is the log of sales (in total dollars sold) of a particular beer in a particular store. Sample includes all craft beer sold by brewers meeting the Brewers Association definition of a craft brewer in Washington, D.C., Delaware, Iowa, Illinois, Indiana, Kentucky, Maryland, Michigan, Minnesota, Missouri, New Jersey, Ohio, Pennsylvania, Virginia, Wisconsin, and West Virginia between 2010 and 2013 . Only 12 oz or 11.2 oz beer sold in packs of six are included in the sample. Time effects are dummy variables at the year level. Time $x$ DMA interactions are interactions between year and Nielsen defined DMAs (Designated Market Area). Time x Retailer interactions are interactions between year and Nielsen retailer id (the identity of retailers is hidden in the data set). Demographic controls include income, education, and alcohol consumption from beer, wine, and spirits at the stateyear level, and the year the state legalized brewpubs. 
Table 35: Fixed Effects Model, Craft Beer Channel Sub-analysis (Dependent variable = Number of Brands Sold in Store)

\begin{tabular}{lcccc}
\hline & $(1)$ & $(2)$ & $(3)$ & $(4)$ \\
\hline Post $\times$ ABI Market Share & -1.155 & $-7.630^{* *}$ & $-36.06^{* * *}$ & -2.369 \\
& $(1.785)$ & $(2.456)$ & $(4.037)$ & $(2.376)$ \\
\hline Observations & 48085 & 301425 & 4067326 & 173558 \\
\hline Store Type & Convenience & Drug & Food & Mass \\
Time Fixed Effects? & Y & Y & Y & Y \\
Time $\times$ DMA Interactions? & Y & Y & Y & Y \\
Time $\times$ Retailer Interactions? & Y & Y & Y & Y \\
Demographic Controls & Y & Y & Y & Y \\
\hline \hline
\end{tabular}

Standard errors in parentheses

${ }^{*} p<0.05,{ }^{* *} p<0.01,{ }^{* * *} p<0.001$

Table 36: *

Dependent variable is the number of macro beer brands sold in a particular store. Sample includes all craft beer sold by brewers meeting the Brewers Association definition of a craft brewer in Washington, D.C., Delaware, Iowa, Illinois, Indiana, Kentucky, Maryland, Michigan, Minnesota, Missouri, New Jersey, Ohio, Pennsylvania, Virginia, Wisconsin, and West Virginia between 2010 and 2013 . Only 12 oz or 11.2 oz beer sold in packs of six are included in the sample. Time effects are dummy variables at the year level. Time $\mathrm{x}$ DMA interactions are interactions between year and Nielsen defined DMAs (Designated Market Area). Time x Retailer interactions are interactions between year and Nielsen retailer id (the identity of retailers is hidden in the data set). Demographic controls include income, education, and alcohol consumption from beer, wine, and spirits at the state-year level, and the year the state legalized brewpubs.

Table 37: Fixed Effects Model, Macro Beer Channel Sub-analysis (Dependent variable $=$ Log of Price)

\begin{tabular}{lcccc}
\hline & $(1)$ & $(2)$ & $(3)$ & $(4)$ \\
\hline Post $\times$ ABI Market Share & $\begin{array}{l}0.0641^{* * *} \\
(0.00608)\end{array}$ & $\begin{array}{l}0.0326^{* * *} \\
(0.00869)\end{array}$ & $\begin{array}{c}\text { 0.0308** } \\
(0.00267)\end{array}$ & $\begin{array}{c}0.0141^{*} \\
(0.00639)\end{array}$ \\
\hline Observations & 267473 & 896323 & 4483428 & 434022 \\
\hline Store Type & Convenience & Drug & Food & Mass \\
Time Fixed Effects? & $\mathrm{Y}$ & $\mathrm{Y}$ & $\mathrm{Y}$ & $\mathrm{Y}$ \\
Time $\times$ DMA Interactions? & $\mathrm{Y}$ & $\mathrm{Y}$ & $\mathrm{Y}$ & $\mathrm{Y}$ \\
Time $\times$ Retailer Interactions? & $\mathrm{Y}$ & $\mathrm{Y}$ & $\mathrm{Y}$ & $\mathrm{Y}$ \\
Demographic Controls & $\mathrm{Y}$ & $\mathrm{Y}$ & $\mathrm{Y}$ & $\mathrm{Y}$ \\
\hline \hline Standard errors in parentheses & & & & \\
${ }^{*} p<0.05^{* *} p<0.01,{ }^{* * *} p<0.001$ & & & &
\end{tabular}

Table 38: *

Dependent variable is the log of price per ounce of a particular beer in a particular store. Sample includes macro beer sold by AB InBev, Constellation, MillerCoors, Heineken, and Pabst in Washington, D.C., Delaware, Iowa, Illinois, Indiana, Kentucky, Maryland, Michigan, Minnesota, Missouri, New Jersey, Ohio, Pennsylvania, Virginia, Wisconsin, and West Virginia between 2010 and 2013 . Only 12 oz or 11.2 oz beer sold in packs of six are included in the sample. Time effects are dummy variables at the year level. Time $x$ DMA interactions are interactions between year and Nielsen defined DMAs (Designated Market Area). Time $x$ Retailer interactions are interactions between year and Nielsen retailer id (the identity of retailers is hidden in the data set). Demographic controls include income, education, and alcohol consumption from beer, wine, and spirits at the stateyear level, and the year the state legalized brewpubs.

Table 39: Fixed Effects Model, Macro Beer Channel Sub-analysis (Dependent variable = Log of Sales)

\begin{tabular}{lcccc}
\hline & $(1)$ & $(2)$ & $(3)$ & $(4)$ \\
\hline Post $\times$ ABI Market Share & -0.0607 & $-0.193^{* * *}$ & $-0.0683^{* * *}$ & 0.0106 \\
& $(0.0615)$ & $(0.0298)$ & $(0.0168)$ & $(0.0414)$ \\
\hline Observations & 267473 & 896323 & 4483428 & 434022 \\
\hline Store Type & Convenience & Drug & Food & Mass \\
Time Fixed Effects? & Y & Y & Y & Y \\
Time $\times$ DMA Interactions? & Y & Y & Y & Y \\
Time $\times$ Retailer Interactions? & Y & Y & Y & Y \\
Demographic Controls & Y & Y & Y & Y \\
\hline \hline
\end{tabular}

Standard errors in parentheses

${ }^{*} p<0.05,{ }^{* *} p<0.01,{ }^{* * *} p<0.001$

Table 40:*

Dependent variable is the log of sales (in total dollars sold) of a particular beer in a particular store. Sample includes macro beer sold by AB InBev, Constellation, MillerCoors, Heineken, and Pabst in Washington, D.C., Delaware, Iowa, Illinois, Indiana, Kentucky, Maryland, Michigan, Minnesota, Missouri, New Jersey, Ohio, Pennsylvania, Virginia, Wisconsin, and West Virginia between 2010 and 2013 . Only 12 oz or 11.2 oz beer sold in packs of six are included in the sample. Time effects are dummy variables at the year level. Time $\mathrm{x}$ DMA interactions are interactions between year and Nielsen defined DMAs (Designated Market Area). Time x Retailer interactions are interactions between year and Nielsen retailer id (the identity of retailers is hidden in the data set). Demographic controls include income, education, and alcohol consumption from beer, wine, and spirits at the state-year level, and the year the state legalized brewpubs. 
Table 41: Fixed Effects Model, Macro Beer Channel Sub-analysis (Dependent variable = Number of Brands Sold in Store)

\begin{tabular}{lcccc}
\hline & $(1)$ & $(2)$ & $(3)$ & $(4)$ \\
\hline Post $\times$ ABI Market Share & -0.985 & 0.130 & -0.311 & 0.780 \\
& $(0.905)$ & $(0.326)$ & $(0.430)$ & $(0.651)$ \\
\hline Observations & 267473 & 896323 & 4483428 & 434022 \\
\hline Store Type & Convenience & Drug & Food & Mass \\
Time Fixed Effects? & Y & Y & Y & Y \\
Time $\times$ DMA Interactions? & Y & Y & Y & Y \\
Time $\times$ Retailer Interactions? & Y & Y & Y & Y \\
Demographic Controls & Y & Y & Y & Y \\
\hline \hline
\end{tabular}

Standard errors in parentheses

$$
{ }^{*} p<0.05,{ }^{* *} p<0.01,{ }^{* * *} p<0.001
$$

Table 42: *

Dependent variable is the number of macro beer brands sold in a particular store. Sample includes macro beer sold by AB InBev, Constellation, MillerCoors, Heineken, and Pabst in Washington, D.C., Delaware, Iowa, Illinois, Indiana, Kentucky, Maryland, Michigan, Minnesota, Missouri, New Jersey, Ohio, Pennsylvania, Virginia, Wisconsin, and West Virginia between 2010 and 2013. Only $12 \mathrm{oz}$ or $11.2 \mathrm{oz}$ beer sold in packs of six are included in the sample. Time effects are dummy variables at the year level. Time $x$ DMA interactions are interactions between year and Nielsen defined DMAs (Designated Market Area). Time x Retailer interactions are interactions between year and Nielsen retailer id (the identity of retailers is hidden in the data set). Demographic controls include income, education, and alcohol consumption from beer, wine, and spirits at the state-year level, and the year the state legalized brewpubs.

Table 43: Fixed Effects Model, Goose Island Beer Channel Sub-analysis (Dependent variable = Log of Price)

\begin{tabular}{|c|c|c|c|c|}
\hline & (1) & (2) & (3) & (4) \\
\hline Post $\times$ ABI Market Share & $\begin{array}{c}0.00354 \\
(0.00770)\end{array}$ & $\begin{array}{c}0.0202 \\
(0.0344)\end{array}$ & $\begin{array}{c}-0.0272^{* *} \\
(0.0103)\end{array}$ & $\begin{array}{l}0.0984^{*} \\
(0.0447)\end{array}$ \\
\hline Observations & 3677 & 13349 & 158450 & 12401 \\
\hline Store Type & Convenience & Drug & Food & Mass \\
\hline Time Fixed Effects? & $\mathrm{Y}$ & $\mathrm{Y}$ & $\mathrm{Y}$ & $\mathrm{Y}$ \\
\hline Time $\times$ DMA Interactions? & $\mathrm{Y}$ & $\mathrm{Y}$ & $\mathrm{Y}$ & $\mathrm{Y}$ \\
\hline Time $\times$ Retailer Interactions? & $\mathrm{Y}$ & $\mathrm{Y}$ & $\mathrm{Y}$ & $\mathrm{Y}$ \\
\hline Demographic Controls & $\mathrm{Y}$ & $\mathrm{Y}$ & $\mathrm{Y}$ & $\mathrm{Y}$ \\
\hline
\end{tabular}

Standard errors in parentheses

${ }^{*} p<0.05,{ }^{* *} p<0.01,{ }^{* * *} p<0.001$

Table 44:*

Dependent variable is the log of price per ounce of a particular beer in a particular store. Sample includes beer produced by Goose Island in Washington, D.C., Delaware, Iowa, Illinois, Indiana, Kentucky, Maryland, Michigan, Minnesota, Missouri, New Jersey, Ohio, Pennsylvania, Virginia, Wisconsin, and West Virginia between 2010 and 2013. Only $12 \mathrm{oz}$ or $11.2 \mathrm{oz}$ beer sold in packs of six are included in the sample. Time effects are dummy variables at the year level. Time x DMA interactions are interactions between year and Nielsen defined DMAs (Designated Market Area). Time x Retailer interactions are interactions between year and Nielsen retailer id (the identity of retailers is hidden in the data set). Demographic controls include income, education, and alcohol consumption from beer, wine, and spirits at the state-year level, and the year the state legalized brewpubs.

Table 45: Fixed Effects Model, Goose Island Beer Channel Sub-analysis (Dependent variable = Log of Sales)

\begin{tabular}{lcccc}
\hline & $(1)$ & $(2)$ & $(3)$ & $(4)$ \\
\hline Post $\times$ ABI Market Share & -0.105 & 0.124 & 0.0973 & -0.0411 \\
& $(0.343)$ & $(0.305)$ & $(0.113)$ & $(0.227)$ \\
\hline Observations & 3677 & 13349 & 158450 & 12401 \\
\hline Store Type & Convenience & Drug & Food & Mass \\
Time Fixed Effects? & $\mathrm{Y}$ & $\mathrm{Y}$ & $\mathrm{Y}$ & $\mathrm{Y}$ \\
Time $\times$ DMA Interactions? & $\mathrm{Y}$ & $\mathrm{Y}$ & $\mathrm{Y}$ & $\mathrm{Y}$ \\
Time $\times$ Retailer Interactions? & $\mathrm{Y}$ & $\mathrm{Y}$ & $\mathrm{Y}$ & $\mathrm{Y}$ \\
Demographic Controls & $\mathrm{Y}$ & $\mathrm{Y}$ & $\mathrm{Y}$ & $\mathrm{Y}$ \\
\hline \hline Standard errors in parentheses & & & & \\
${ }^{*} p<0.05,{ }^{* *} p<0.01,{ }^{* * *} p<0.001$ & & & &
\end{tabular}

Table 46: *

Dependent variable is the log of sales (in total dollars sold) of a particular beer in a particular store. Sample includes beer produced by Goose Island in Washington, D.C., Delaware, Iowa, Illinois, Indiana, Kentucky, Maryland, Michigan, Minnesota, Missouri, New Jersey, Ohio, Pennsylvania, Virginia, Wisconsin, and West Virginia between 2010 and 2013 . Only $12 \mathrm{oz}$ or $11.2 \mathrm{oz}$ beer sold in packs of six are included in the sample. Time effects are dummy variables at the year level. Time x DMA interactions are interactions between year and Nielsen defined DMAs (Designated Market Area). Time x Retailer interactions are interactions between year and Nielsen retailer id (the identity of retailers is hidden in the data set). Demographic controls include income, education, and alcohol consumption from beer, wine, and spirits at the state-year level, and the year the state legalized brewpubs. 